\title{
Priority of Future Advances Lending Under the Uniform Commercial Code
}

\section{INTRODUCTION}

Although the Uniform Commercial Code seems to exhaustively detail the priorities to be given the security interests created by its revolutionary Article 9, recent commentary ${ }^{1}$ has revealed that the Code's priority treatment is somewhat less than complete. When either lien creditor or holder of a security interest perfected other than by filing intervenes between disbursements made by a lender who is financing by means of a secured future advances loan, the Code does not clearly assign the priority of advances made subsequent to that intervention. This comment explores three areas. First, it briefly examines the historic and potential uses of future advances lending. By demonstrating the commercial utility of future advances lending the importance of a clear statement of priority for this type of financing is made more apparent. Second, it discusses at somewhat greater length the Code's obscure and ambiguous "treatment," or more frankly, lack of treatment. of future advances priorities. It develops that the Code does not really give any shape to the concept of the "security interest," despite the fact that security interests represent the major concern of Article 9. Thus, similar to difficulties concerning proceeds and shifting

1 See P. Coogan, W. Hogan, \& D. Vagts, Secured Transactions Under the Uniform Commercini Code $\$ 7.03$ at $689, \$ 15.09$ at 1606 (1963); G. GLimore, 2 SeCURITY INTERESTS IN PERSONAL. Property \& 35 (1965) [hereinafter cited as GILMORE]; Coogan, Intangibles as Collateral Under the Uniform Commercial Code, 77 HARv. L. REv. 997 (1964) [hereinafter cited as Coogan, 77 HARv. L. REv. 997]; Coogan, Article 9 of the Uniform Commercial Code: Priorities Among Secured Creditors and the "Floating Lien," 72 Harv. L. REv. 898 (1959) (earlier version of CoOGAN, HoGAN, \& VAGrs, supra \& 7.03) [hereinafter cited as Coogan, 72 HARv. L. REv. 838]; Coogan \& Gordon, The Effect of the Uniform Commercial Code Upon Receivables Financing-Some Answers and Some Unresolved Problems, 76 Harv. L. REv. 1529 (1963) (original of COOGAN, HOGAN \& VAGTs, supra, $\$$ 15.09) [hereinafter cited as Coogan \& Gordon, 76 HARv. L. Rev. 1529]; Goodwin, Priorities in Secured Transactions-Article 9, Uniform Commercial Code, 20 Bus. LAw. 877 (1965); Section of Corporation, Banking and Business Law of the American Bar Association, A Practical Approach to the Uniform Commercial Code for the Practicing Lawyer, 19 Bus. LAw. 5 (1963); Marsh, Book Review, 13 U.C.L.A.L. REv. 898 (1966); Young, Book Review, 66 Colum. L. REv. 1571 (1966). 
stock, 2 the extent of the secured party's priority will depend upon resolution of the conceptual problem of the security interest's continuity or "spread." Finally, this comment suggests an approach to solution of future advances priorities.

\section{Uses of Secured Future Advances Lending}

Just about anyone can lend using a secured future advances lending arrangement. If the cases are any indication, however, these lenders tend to be merchants, bankers, and new-style factors. But a secured future advances borrower is someone special, because he can only meet his capital requirements if he is able to fund his enterprise bit by bit and offer security. Current writing on the subject of secured future advances loans gives the impression that they are used chiefly if not solely to finance building construction. ${ }^{3}$ However, as earlier writers have noted, ${ }^{4}$ the secured future advances loan was used in a variety of contexts. ${ }^{5}$ This broad range of applicability makes sense if one considers this lending device from a functional point of view.

There appear to be several prerequisites which must be met before a secured future advances arrangement will be utilized. First, of course, the borrower must be in a sufficiently risky financial position so that the lender demands security; he must be unable to get his loan except on a secured basis. ${ }^{\circ}$ Second, the law must make valuable property available

2 See, e.g., Ray Henson's literate account of the "proceeds" problem in Henson, "Proceeds" under the Uniform Commercial Code, 65 Corum. L. REv. 232 (1965).

3 "The institutional transaction out of which future advance law grew was the building construction loan. In time the device was adapted to working capital loans with the mortgage covering both the real and personal property of the mortgagor enterprise." GILMORE § 35.3, at 925. See also Note, Mortgages Securing Future Advances-A Need for Legislation, 47 Iows L. REv. 432 (1962); Note, Refinements in Additional Advance Financing: The "Open End" Mortgage, 38 Mins. L. REv. 507 (1954).

4 See, e.g., G. Osborne, Mortgages $\S 113$ (1951) [hereinafter cited as OsBorne]: “There are many transactions in which business desirability is heavily on the side of a mortgage securing [future advances]. . . Typical of such dealings are construction or improvement loans with installments to be advanced as the work progresses; mortgages by way of indemnity for prospective indorsements, guarantees, and accommodations of commercial paper to be issued by the mortgagor; fluctuating current balances under lines of credit established with the mortgagee; and as security for a bond issue, or a series of issues." See also 1 G. Glenn, Fraudulent Conveyances and Preferences $\$ 372$ (rev. ed. (1940); Jones, Mortgages Securing Future Advances, 8 TEX. L. REv. 371, $371-72$ (1930).

5 Under discussion here are what might be termed "legitimate" future advances lending arrangements. Some lenders may ciaim that an indebtedness which has no relation to a given future advances lending arrangement falls under the protection of a broad future advances clause. Assertions of priority for such unrelated obligations, appropriately and colorfully termed "Anaconda mortgages," have been rejected by the courts. See Gilmore \$35.2.

6 See A. SWEetser, Financing Goods 123 (1963). 
as collateral. ${ }^{7}$ In the last half-century at least, the history of the financing of business is in part the history of an attempt by lenders, courts, and legislatures to open up new sources of collateral. ${ }^{8}$ Third, the lender must be unwilling to make his loan except bit by bit, ${ }^{9}$ and the borrower must be able to make use of the loan in this form. For example, the manufacturer of textiles whose production involves a number of time-consuming interrelated steps may be able to take advantage of a future advances loan. ${ }^{10}$ Fourth, the collateral must be, or must be capable of becoming, valuable enough to cover the entire sum of advances.

Given these prerequisites, the employment of future advances lending in a construction loan is understandable. The home builder, for example, can put up his undeveloped plot of land as collateral through a mortgage. His real estate can increase in value as the borrowed money is applied to its improvement. Legally, the improvements would be welded to the real estate by the doctrine of "fixtures" of "accessions," 11 thus swelling the collateral and the size of the available secured loan. The lender can minimize the risk of his investment by disbursing the loan bit by bit. Furthermore, the home builder does not need a lump sum at the outset; he needs a continuing supply of capital to pay for work and materials as building progresses. The home builder, then, is able to secure a loan which in the aggregate might exceed the initial value of the security he is able to offer. Under such conditions the frequent employment $t^{12}$ of the future advances loan for building construction is not surprising.

It should be realized, however, that future advances lending was in wide use as early as the nineteenth century to fund entrepreneurial activity in areas other than building construction..$^{13}$ In the early English

7 The Code increases the range of such property available for use as collateral. UNIFORM COMMERCIAI CODE \& 9-105(1)(c) (1958 version) [hereinafter cited as UCC]. See generally Coogan \&: Gordon, 76 HARv. L. REv. 1529.

8 For an eminently readable account of this history see GIrMore $\$ \$ 1-8$.

- See Kripke, Current Assets Financing as a Source of Long-Term Capital, 36 MINN. L. Rev. 506, 513 (1952).

10 See A. Sweetser, Financinc Goods 121 (1963).

11 See, e.g., Coogan, Security Interests in Fixtures Under the Uniform Commercial Code, 75 HARv. L. REv. 1319 (1962); Kripke, Fixtures Under the Uniform Commercial Code, 64 Colum. L. Rev. 44 (1964).

12 Note, Mortgages Securing Future Advances: A Need for Legislation, 47 Iowa L. REv. 432 (1962).

18 Every early "leading" case in the future advances field shows the use of the future advances mortgage of real estate either to provide or to underwrite working capital for business enterprise. See Shirras v. Craig, 11 U.S. (7 Cranch) 34 (1812) (financing of merchants); Ackerman v. Hunsicker, 85 N.Y. 43 (1881) (indorsing business firm's notes); Robinson $\nabla$. Williams, 22 N.Y. 380, 383 (1860) (mortgage of bank premises to cover 
case, Hopkinson $v$. Rolt, ${ }^{14}$ often cited as a leading authority in the future advances field, a merchant used a future advances loan to provide working capital for his shipbuilding business, putting up his considerable real estate holdings as security. The history of the use of this type of lending seems to indicate that real estate was unsatisfactory as collateral, since the entrepreneur would need valuable real estate holdings initially or would have to pour the borrowed money into the improvement of his existing, less valuable real estate. The appearance of more attractive collateral may, indeed, have been the reason for the curious disappearance, toward the close of the nineteenth century, of reports of loans like that in Rolt. ${ }^{15}$ As new sources of collateral opened up, ${ }^{16}$ first by common law factor's lien and trust receipt, then by so-

fluctuating balance); Hopkinson v. Rolt, 9 H.L. Cas. 514, 11 Eng. Rep. 829 (1861) (working capital for shipbuilder).

For like use of the future advances device, see Bell v. Radcliff, 32 Ark. 645 (1878) (deed of trust of cotton crop to secure advances of supplies needed by partnership to cultivate a plantation); Tapia v. Demartini, 77 Cal. 383, 19 P. 641 (1888) (mortgage to cover equipment sold to mining partnership); Langerman v. Puritan Dining Room Company, 21 Cal. App. 637, 132 P. 617 (1913) (mortgage to secure line of credit to dining room company); Boswell v. Goodwin, 31 Conn. 74 (1862) (mortgage to cover indorsement of paper manufacturer's notes and advances); Weiser Loan \& Trust Co. v. Comerford, 41 Ida. 172, 238 P. 515 (1925) (mortgage to secure fluctuating balance); Speer v. Skinner, 35 Ill. 282 (1864) (hotel fumiture mortgaged by hotel operators to secure advances of working capital); Collins v. Carlile, 13 III. 254 (1851) (mortgage by merchant to cover purchases of goods from 2 St. Louis distributor); Louisville Banking Co. v. Leonard, $90 \mathrm{Ky}$. 106, 13. S.W. 521 (1890) (mortgage to secure discount of customer notes of furniture manufacturer); Downing v. Palmateer, 17 Ky. (1 T.B. Mon.) 64 (1824) (mortgage of female slave to cover advances of liquor and other necessaries to tavern keepers in Lexington); Hall v. Jay, 131 Mass. 192 (1881) (mortgage to secure purchases of coal by a retail coal-dealer from a wholesaler); Commercial Bank v. Cunningham, 41 Mass. (24 Pick.) 270 (1837) (mortgage to secure future indemnities); McDaniels v. Colvin, $16 \mathrm{Vt}$. 300 (1884) (mortgage to cover what may be owed "on book"); Brinkerhoff v. Marvin, 5 Johns. Ch. R. 320 (N.Y. 1821); Hendricks v. Robinson, 2 Johns. Ch. 283 (N.Y. 1817). Early cases showing use of future advances for building construction do exist, but their appearance in the reports is infrequent until near the turn of the century. See Crane v. Deming, 7 Conn. 386 (1829) (mortgage to secure advances for construction of a bridge over the Passaic River); Barry v. Merchants' Exchange Co., I Sandf. Ch. 280 (N.Y. 1844) (mortgage to construct "a granite fire-proof building [in New York], which should be commensurate to the wants, as well as honorable to the munificence of the commercial metropolis of the western world').

149 H. L. Cas. 514, 11 Eng. Rep. 829 (1861).

15 There are, of course, many reasons why a given type of case may disappear from reported cases, and perhaps even more reasons why the transaction itself may cease to be used. As regards the particular type of lending arrangement under discussion, it may be, for example, that the proportion of borrowers of working capital who owned real estate decreased toward the end of the nineteenth century. Since the collateral was not available, the loans were not made.

16 For development of twentieth-century availability of accounts receivable, inventory, and contract rights as collateral, see GILMORE \$ई 5-8, 41.1; Dunham, Inventory and Accounts Receivable Financing, 62 HARv. L. REv. 588 (1949); Kripke, The "Secured Transactions" Provisions of the Uniform Commercial Code, 35 VA. L. Rrv. 577 (1949); Skilton, 
called factor's lien acts, accounts receivable and trust receipt legislation, ${ }^{17}$ future advances lending remained, ${ }^{18}$ but new kinds of security for financing the same transaction seemed to supplant the old.19 Consequently, mortgages of real estate to secure future advances still exist only where they are functionally appropriate, as in the building construction field.

The trend of future advances lending practices indicates its continuing use to finance risky entrepreneurial activity with increasingly exotic forms of security: real estate and chattels to contract rights to the Code's wispy "general intangibles." With a device of such apparent usefulness, the priority which the Code accords it in default situations holds special interest.

\section{The Code's Presently Ambiguous Treatment of Future Advances Priorities}

\section{A. The Problem}

Unfortunately, the Code has not clearly specified the priority which a future advances lender will receive over other creditors of the borrower should resort to security be necessary. ${ }^{20}$ This ambiguity may affect the availability of the secured future advances loan.

The Factor's Lien on Merchandise, 1955 Wrs. L. REv. 356; Steffen \& Danziger, The Rebirth of the Commercial Factor, 36 CoLvm. L. REv. 744 (1936); Comment, Financing Inventory Through Field Warehousing, 69 Yare L.J. 663, 670 (1960); Comment, Contract Rights as Commercial Security-Present and Future Intangibles, 67 YALE L.J. 847 (1958).

17 See Gumore \$ 1-8; Kripke, The "Secured Transactions" Provisions of the Uniform Commercial Code, 35 VA. L. REv. 577 (1949); Skilton, The Factor's Lien on Merchandise, 1955 WIs. L. REv. 356, 609; Steffen \& Danziger, The Rebirth of the Commercial Factor, 36 COLUM. L. REv. 744 (1936).

18 The following illustrate the use of the future advances loan in a variety of contexts: The Seattle, 170 F. 284 (9th Cir. 1909); In re Cichanowicz, 226 F. Supp. 288 (E.D.N.Y. 1964); Reidy v. Collins, 134 Cal. App. 713, 26 P.2d 712 (1933); Hance Hardware Co. v. Denbigh Hall, Inc., 17 Del. Ch. 234, I52 A. 130 (Ch. Ct. 1930); New York \& Suburban Fed. Sav. \& Loan Ass'n v. Fi-Pen Realty Co., 133 N.Y.S2d 33 (Sup. Ct. 1954); In re Harris' Estate, 156 Misc. 805, 282 N.Y.S. 571 (Surr. Ct. 1985); Housing Mortgage Corp. v. Allied Constr. Inc., 374 Pa. 312, 97 A.2d 802 (1953).

19 Coogan \& Gordon, 76 Harv. L. Rev. 1529, 1530 n.2. For examples of the use of new collateral for similar transactions, see Rockmore v. Lehman, 128 F.2d 564 (2d Cir. 1942), rev'd on rehearing, 129 F.2d 892 (2d Cir. 1942) (contract rights used to secure future advances); In re New York, N.H. \& H.R.R. Co., 25 F. Supp. 874 (D.C. Conn. 1938) (assignment of contract rights to secure future advances).

20 The Code is not the only statutory enactment guilty of ambiguity on the question of future advances priority. A similar brouhaha developed over the question of priority under the new Federal Tax Lien Act. See W. Plumb \& L. Wright, Federar. TAx Liens 77 (2d ed. 1967); Young, Priority of the Federal Tax Lien, 34 U. CHI. L. REv. 723 (1967). A. similar confusion may exist on the question of priority for future advancing real estate mortgages over fixtures subject to a security interest held by a Code secured party. See, e.g., 
A hypothetical situation ${ }^{21}$ in which the priority question arises will illustrate the Code's presently ambiguous treatment of priority for the future advancing secured lender. A merchant financer agrees to loan a farmer 1,000 dollars to be paid out at the lender's discretion during the course of the growing season. As security the merchant takes a "security interest" in the farmer's agricultural equipment. The merchant files his "financing statement" in the proper administrative offices. After crops have been harvested, but before the 1,000 dollars has been completely disbursed, one of the farmer's general creditors obtains judgment against him. Subsequently, the merchant makes a further discretionary advance of the remainder of the 1,000 dollars with actual notice of the intervening attachment. The farmer defaults in his payments to the lender, perhaps because the crops have not brought the price expected, and the merchant finally brings action to foreclose his security interest in the farmer's equipment. Since the farmer's equipment is not valuable enough to satisfy both the merchant and the creditor, a dispute over priority arises. In this situation (or in another involving an intervening secured creditor who perfects his security interest other than by filing), i.e. when a party breaks the stream of the secured party's advances, whether those advances were made at the secured party's pleasure or pursuant to a binding commitment, the question of the priority to be awarded advances made after the break arises.

\section{B. Code Treatment}

If, to answer the question, resort is made to explicit treatment of the priorities in the Code, the search will be in vain. Unlike its treatment of some security interest priorities, the Code has no provision which specifically details the priority to be given a future advances security interest over other, intervening interests. ${ }^{22}$ It does have a pro-

Comment, Fixtures in the Landlord-Tenant Relationship, 34 U. CHI. L. REv. 617, 630 n.71 (1967).

21 This situation is an embroidered version of the facts in Lovelace v. Webb, 62 Ala. 271 (1878). Cf. McNeill v. Conyers, 80 S.C. 571, 61 S.E. 1068 (1901).

22 Since there is no explicit provision which governs the priority of the future advancing lender over the intervening lien creditor or secured party who perfects other than by filing, a rule may be provided by resort to pre-Code priority rules. California apparently noticed the Code's "applicability gap" and closed it by grafting its statutory pre-Code priority rule onto its version of Code section 9-312. This new subsection (7) of 9.312, CAL. STATS. ch. 819 (1963), provided: "The secured party takes priority as to the future advances specified below from the time his security interest was originally perfected: (2) If a maximum amount to be secured is stated in the filed financing statement (or in a security agreement where a financing statement is not required to be filed), as to all advances up to that amount outstanding at any one time (without regard to advances already repaid or discharged), whether the making of such advances is optional with or obligatory upon 
vision of general applicability, section 9-312(5), ${ }^{23}$ which assigns future advances priority in some situations. Thus, if a contest is between two secured lenders who have "perfected" their security interest by filing, the first to file wins. But if the intervening party has a security interest "perfected" other than by filing, or is an unsecured but "lien creditor," those Code provisions which are of general applicability, sections $9-312(5)^{24}$ and $9-201,25$ do not unambiguously assign priority. They fail to assign priority because the extent or spread of the "security interest" created by the disbursements of a future advances loan has not been articulated by the Code. Once this conceptual problem is answered, priority may be deduced from the Code's general, catch-all sections.

The Heraclitian metaphysics required to formulate a concept of the security interest created by the multiple disbursements of a future advances arrangement is similar to that involved in the visualization of the so-called "floating lien." The "floating lien" is like a cloud drift-

the secured party; (b) If a maximum amount to be secured is not so stated, as to all obligatory advances, and as to all optional advances made by the secured party without knowledge of an intervening right; and (c) In all cases as to advances and expenditures made by the secured party for the protection, maintenance, preservation or repair of the collateral ...." The subsection was roundly criticized in Coogan, 77 HARv. L. REv. 997, 1021, largely on the ground of its unduly broad scope. Its repeal, GaI. Stats. ch. 1379, \& 17 (1965), was apparently the result of this criticism. See Californin Continung Education of the BAR, REVIEW OF SELEGTED 1965 CODE LlegisLation 103 (1966).

However, no specific legislative enactment of a pre-Code priority rule-a rule whose formulation is discussed in the text following note 65-may be needed to supply a rule where the Code leaves a gap. Section 10-102(3) of the Code provides for particular and general repeal of previous legislation regulating personal property secured transactions. Since the Code sweeps away only previous legislative regulation of future advances priorities and arguably provides no substitute in its stead, it may be asserted that the preCode common law rule of future advances priority has continued or has renewed validity. Arguably, then, the repeal of section 9-312(7) by the Californiz legislature had the effect of reinstating its common law priority rule. See, e.g., Reidy v. Collins, $134 \mathrm{Cal}$. App. 713, 26 P.2d 712 (1933).

23 UCC \& 9-312(5): "In all cases not governed by other rules stated in this section (including cases of purchase money security interests which do not qualify for the special priorities set forth in subsections (3) and (4) of this section), priority between conflicting security interests in the same collateral shall be determined as follows:

(a) in the order of filing if both are perfected by filing ....."

24 UCC \& 9-312(5)(b): "In all cases not governed by other rules stated in this section (including cases of purchase money security interests which do not qualify for the special priorities set forth in subsections (3) and (4) of this section), priority between conflicting security interests in the same collateral shall be determined as follows:

(b) in the order of perfection unless both are perfected by filing, regardless of which security interest attached first under Section 9-204(1) and, in the case of a filed security interest, whether it attached before or after filing. ..."

25 UCC \& 9-201: "General Validity of Security Agreement. Except as otherwise provided by this Act a security agreement is effective according to its terms between the parties, against purchasers of the collateral and against creditors. . . ." 
ing over a river; ${ }^{26}$ the shadow cast remains the same, but the substance passing under the shadow is in a state of constant flux, of continuous depletion and replenishment. The lien created in inventory financing, then, can be said to float over the shifting inventory of the borrower just as a cloud floats over an ever-changing river. In the future advances context, attention shifts from the water below to the cloud above. The available definitions of the "security interest" concept may be framed in terms of our cloud analogy. Disbursements either create a security interest which is like one big cloud that mushrooms as further advances are made; or they create security interests incapable of growth, so that the advances generate a separate security interest-cloud-for each advance, each equal in extent to the value given or promised to be given by the secured lender at that time. Once a decision is made as to the extent of the security interest or interests created by the disbursements, the priority to be given the future advances secured lender follows as the result of a rather long deductive chain.

The beginning point of the chain is either section $9-312(5)(b),{ }^{27}$ if the intervening party is another secured creditor, and he or the future advances lender has "perfected" other than by filing; or sections 9-20128 and $9-301(1)(b),{ }^{29}$ if the intervening party is a lien creditor without notice ${ }^{30}$ of the security interest. If the intervening party is another

26 Skilton, The Factor's Lien on Merchandise, 1955 WIs. L. REv. 609, 631.

27 See note 24 supra.

28 See note 25 supra.

29 UCC \& 9-301: "(1) Except as otherwise provided in subsection (2), an unperfected security interest is subordinate to the rights of ....

(b) a person who becomes a lien creditor without knowledge of the security interest and before it is perfected; ...

(3) A "lien creditor" means a creditor who has acquired a lien on the property involved by attachment, levy or the like and includes an assignee for benefit of creditors from the time of assignment, and a trustee in bankruptcy from the date of the filing of the petition or a receiver in equity from the time of appointment. ..."

30 The Code does not specify whether actual or constructive knowledge of the security interest will destroy the lien creditor's priority over an unperfected security interest. See note 29 supra. Were an actual knowledge construction adopted, then, in the future advances context, the secured lender, to assure himself of priority over intervening lien creditors would need, as a practical matter, to notify all the borrower's general creditors of his financing arrangement before he gave "value" to the borrower. After this initial mass notification and after the first giving of "value," the secured lender in a discretionary advances arrangement would, under the interpretation of the Code in which discretionary advances create a series of perfected security interests (see text accompanying note 26 supra), need to take the further step of notifying each of the borrower's general creditors. Were a constructive knowledge interpretation of section 9-301(1)(b) adopted, then, presumably the secured lender would need only to file to give the intervening lien creditors constructive notice. He would then be assured of priority if his advances fell under a security interest which was perfected before the intervening party became a lien creditor of of the borrower. 
secured party, then section $9-312(5)$ (b) directs that he who is first to "perfect" his security interest receives priority. If the intervening party is a lien creditor, then sections 9-201 and 9-301(1)(b) when read together yield the negative implication that the secured party, in order to take priority over the lien creditor must have "perfected" his security interest. "Perfection" of the future advancing party's security interest is thus crucial to the secured lender's priority over either of the intervening parties.

Perfection of a security interest is accomplished by a number of steps outlined in related sections of the Code. Under section 9-303: "A security interest is perfected when it has attached and when all of the applicable steps required for perfection have been taken. Such steps are specified in sections 9-302, 9-304, 9-305, and 9-306 . . ." A security interest has "attached" when, among other things, "value" has been given by the secured party. ${ }^{31}$ Section 1-201(44) defines the giving of value:

... [A] person gives "value" for rights if he acquires them (a) in return for a binding commitment to extend credit ... (d) generally, in return for any consideration sufficient to support a simple contract.

Thus, assuming all other steps of section $9-303^{32}$ have been taken, a future advances security interest is "perfected" either when the lender makes his first advance or, if advances are made pursuant to a binding commitment, at the time when the security agreement is accepted.

Having perfected a security interest, the future advancing lender, under the provisions of section $9-312(5)(b)$ on sections 9-201 and $9-301(1)(b)$, can be assured of priority over the secured party or lien creditor to the extent of his previously existing security interest. At this point the cloud analogy becomes relevant, for where discretionary advances are made the extent of the security interest created by those advances must be determined. If many discrete security interests are created, ${ }^{83}$ a gap develops which allows a lien creditor to slip in before a subsequent, perfected security interest is created by a subsequent

31 UCC \& 9-204: "A security interest cannot attach until there is agreement (subsection (3) of Section 1-201) that it attach and value is given and the debtor has rights in the collateral. It attaches as soon as all of the events in the preceding sentence have taken place unless explicit agreement postpones the time of attaching."

32 UCC \& 9-303: "A security interest is perfected when it has attached and when all of the applicable steps required for perfection have been taken. Such steps are specified in Sections 9.302, 9-304, 9-305 and 9-306. ..."

33 This conception is adopted by Coogan. See Coogan, 77 HARv. L. Rev. 997. 
advance. ${ }^{34}$ If a single, mushrooming security interest is created, ${ }^{35}$ then all advances are embraced and continuously perfected from the time value is first given. ${ }^{36}$ Under the first or discrete interest view of the future advances security interests, the secured party is given priority over the intervening lien creditor only for subsequent advances made pursuant to a binding commitment; his discretionary advances are subordinated. Under the second or single interest view, the secured party is always given priority once his security interest has "attached" either by executing a binding commitment to make advances or by making the first advance.

\section{The Current Debate Among the Commentators Over THE "PROPER" INTERPRETATION OF THE "SEGURTTY INTEREST"}

Thus, either of two rules of priority may be deduced from the Code. Supporters with impressive credentials may be found for either view. Their arguments, generally emphasizing the question of what is the "proper" conception of the Code "security interest," seem inconclusive at most. The thrust of these arguments, generally, is that the proffered conception is most consistent with companion provisions of the Code. These arguments, along with their corresponding counterarguments, could be set out as follows:

1. Since the future advances agreement seems analogous to the after-acquired property clause, which, under subsections (1) and (2) of section 9-204, creates a series of security interests as the debtor obtains rights in the collateral, the future advances relationship, like the afteracquired property clause, should create a series of security interests as well. To avoid conceptual inconsistency, then, a discrete interests view should be adopted. ${ }^{37}$

In reply to this argument a distinction between the concept of old rights in new collateral and the concept of new rights in old collateral may be drawn. There is, therefore, no conceptual inconsistency when

34 Under this view, only when advances are given pursuant to a binding commitment will they relate back to the time of perfection under the initial agreement. Priority given to these obligatory advances may be conceptually rationalized by saying that they represent a part of the value of the security interest whose extent was fixed by the security agreement.

35 This conception is adopted by Professor Gilmore. See Gilmore $§ \S$ 35.6, 35.7.

36 Thus, assuming the lender has met all requirements of \$ 9-303 except "attachment," the lien creditor or other secured party, in order to take priority over the future advancing lender, must achieve lien creditor status or perfect his security interest either before a binding commitment is executed or, if advances are given at the lender's discretion, before the first advance is made.

37 See Coogan, 77 Harv. L. Rev. 997, 1028; Coogan, 72 HaRv. L. Rev. 838, 868. 
differing priority rules which embody these different concepts are used in differing situations. Even though under section 9-204(1) a series of security interests arises as the debtor acquires rights in the collateral, it does not follow that the secured party's interest in after-acquired property will be subordinated to the interest of intervening secured or lien creditors, since the debtor acquires rights in his collateral subject to the rights of the secured party. Just because collateral is acquired in lumps, then, does not mean that rights in that collateral must be also. ${ }^{88}$

2. Under section 9-204(1) a security interest cannot attach until "value is given"; section 1-201(37) states that a security interest "secures payment or performance of an obligation." Thus, each time the debtor becomes obligated to repay the lender-and new obligations are being created with every advance-a new security interest is created to secure performance of his obligation. Therefore, a series of discrete security interests is created..$^{30}$

In reply it may be said that sections $9-204(1)$ and 1-201(37) speak only to the creation of security interests, not their extent. There is nothing inconsistent between these sections and the opposing single interest view of the security interest. One may grant that an obligation is created when value is given, and merely add that the security interest, once created to secure payment or performance of an obligation, may continue to grow as more obligations fall under its protection. A series of obligations does not preclude a single, mushrooming security interest which grows to embrace those obligations.

3. UCC section $9-311$ reads:

The debtor's rights in collateral may be voluntarily or involuntarily transferred ... notwithstanding a provision in the security agreement prohibiting any transfer or making the transfer constitute a default.

The single interest view, which gives priority even as to discretionary advances, would appear to frustrate the spirit of section 9-311 if a lender were allowed by a single agreement to make discretionary advances and in effect mortgage all the debtor's property away. Such agreements would appear to seriously impair the ability of the debtor voluntarily or involuntarily to transfer his rights in the collateral, since few would be found, except perhaps a buyer in the ordinary course of business, who would buy an equity in collateral which could be swallowed up by subsequent discretionary advances by the secured lender. ${ }^{40}$

38 See GiLMORe \& 35.6, at 936-37. Cf. OsBorne, \& 114, at 277-78 (1951).

s8 See Coogan, 77 HARv. L. REv. 997, 1028; Coogan, 72 HARv. L. REv, 838, 868.

40 See Coogan, 77 Harv. L. REv. 997, 1029, 1034; Coogan \& Gordon, 76 Harv. L. REv. 1529, 1550; Coogan, 72 HARv. L. REv. 838, 868. 
It is true, as the argument suggests, that the debtor is to be left the ability to transfer his rights in collateral. But he may transfer them, as the section itself declares, by creation of a security interest. The Code gives full validity to both after-acquired property clauses and future advances arrangements. Under section 9-312(5)(a): “. . . priority between conflicting security interests in the same collateral shall be determined as follows: (a) in the order of filing if both are perfected by filing ...." If a debtor chooses, therefore, to transfer all his rights in collateral to a single secured party the Code seems to offer no objection and will protect the secured party against a later filing by a secured party. ${ }^{41}$

4. For purposes of priority there seems to be no predisposition in the Code against the division of obligations into parts, as required by the discrete interests view. Where, for example, part of a debt is a purchase money obligation, the purchase money interest is entitled to priority over conflicting security interests under section 9-312(3) and (4). Thus, there would be no conceptual inconsistency in saying that for purposes of priority each discretionary advance by the future advancing lender creates a separate security interest. ${ }^{42}$

It may be answered that because the Code divides obligations in some areas does not mean that it must do so in others. For example, the reasons for giving a purchase money interest priority over other obligations may be quite different from reasons for allowing or not allowing priority to the future advancing lender for his discretionary advances. ${ }^{43}$

\section{Policy Perspectives of the Alternative Rules}

It is possible to argue, then, about the "proper" conception of the security interest, but these mildly persuasive arguments seem about in balance. Perhaps the real issue dividing the commentators, and what seems a more relevant concern in any event, involves assessments of the most desirable policy or policies which a priority rule should further. Choice of policy is a political question; evaluation of the efficacy of a priority rule in furthering a policy is an empirical question. Although this comment cannot purport to conclusively answer either question, analysis is measurably advanced by at least asking them. In deciding who should win a priority contest, a range of policies could be considered.

First, on the broadest level of inquiry one can ask whether it is

11 See GILMORE \& 35.6 n.3.

42 See Coogan, 77 HArv. L. Rev. 997, 1028, 1030.

13 Cf. Coogan, 72 Harv. L. REv. 838, 861; Gilmore, The Purchase Money Priority, 76 HARV. L. REV. 1333 (1963). 
desirable to promote secured credit. It could be argued, as it has been argued, ${ }^{44}$ that the future advances lending device is basically a beneficial mechanism which promotes the infusion of capital into business enterprises which otherwise could not exist. Given this premise, that priority rule which least hinders the lending device could be chosen.

Second, one could argue that secured credit is basically to be avoided since secured lenders already possess too much power over the economically disadvantaged borrowers who must take a future advances loan and give security. It would seem to follow that the discrete interest view of the security interest, which loosens the secured creditor's grip on the debtor's assets, would be preferable.

Of course, one's inquiry need not be so far-reaching or politically conscious. Other, narrower questions could be considered. A third approach would be to award priority between the two immediate parties on the basis of the fairest solution. Obviously, any number of factors of greater or lesser particularity might be relevant in deciding what award of priority is most "fair." But certain factors, such as the secured lender's actual knowledge of intervening interests may claim a special place in equitable considerations. On the other hand, it may be argued that harsh consequences must be tolerated if other considerations are sufficiently compelling. The Code is not devoid of its harsh rules. As a chief proponent of the discrete interests view has noted:

Although the application of a priority rule in a particular situation usually has a basis in common sense, the priority rules of the Code are in many ways as arbitrary as the rule in a bridge game that says that an ace takes priority over a king ....

... [S]ometimes the secured party who does nothing to put others on guard gets a higher priority than he would have attained had he taken all steps possible to put others on notice of his secured claim. ${ }^{45}$

In the next three sections these three policies are considered in greater detail. As the discussion suggests, the impact of either priority rule on any one of these policies is difficult to assess. ${ }^{48}$

44 See Ackerman v. Hunsicker, 85 N.Y. 43 (1881).

46 Coogan \& Gordon, 76 HARv. L. REv. 1529, 1563-64.

46 At least eight successive drafts of the Code contained some provision which expressly provided for future advances priority over some third party. Since the last of these provisions was deleted in ALI \& NAtional Conference of Commissioners on UnIForm State Laws, 1952 Official Draft of Text and Comments of the Uniform Commercial Code 
74 (Supp. I, 1955) (for discussion of this deletion, see Coogan, 77 HARv. L. REv. 997, 1020 n.69), there has been no revival of explicit future advances priorities treatment.

However, a brief statutory history provides material for either side of the current debate. Compare 1 ALI \& National Conference of Commissioners on Uniform State Laws, Revision of Article 7 for Use in July 25-27, 1949 Meeting 47, 49 (1949) (unpublished early draft of the secured transactions section in University of Chicago Law School Library) text:

Section 7-406. Priorities Among Security Interests.

-...

(2) In the case of goods other than inventory

....

(b) an interest attaching by reason of new value given after an earlier lender has perfected an interest in the same collateral takes precedence over the first perfected interest to the extent the first perfected secured value given after notice was given by the later lender to the first lender if such notice was given not more than ten days before the new value was given and indicates the amount of value given and the collateral claimed....

and corresponding Comments:

A lender may advance $\$ 50,000$ and take back a security interest in plant equipment worth $\$ 100,000$. It should then be possible for the borrower to borrow on his remaining equity and if a different lender makes the second advance, his interest should, although subordinate to the interest securing the earlier $\$ 50,000$ advance [be] protected against an interest later claimed by the first lender arising out of subsequent advances. The first lender, on the other hand, is entitled to notice that a subsequent lender now claims an interest in the hitherto available equity. Subsection (2)(b) adopts the approach above outlined, the second lender's protection against subsequent advances by the earlier lender being conditioned on his giving ten days notice before new value given.

with 2 ALI \& National Conference of Commissioners on Uniform State LAws, UNIForm Commercial Code-Proposed final Draft 777-79 (1950) text:

Section 9-312. Conflicting Security Interests.

Except as otherwise provided ... when conflicting security interests attach to the same collateral, such interests rank in the order of time of perfection with the following exceptions:

(1) An interest attaching after a financing statement has been filed takes priority from the time of its filing. Unless otherwise agreed to by the earlier lender such priority holds also as to later advances made by him under the statement.

and Comments:

Lender A makes one loan on equipment; lender B then makes an advance on the same collateral. Lender $A$ makes an additional advance claiming his "future" advance is entitled to the same priority as his first.

... [This] is a problem which frequently arises in chattel mortgage situations where a mortgagee is financing an entire operation but loans one sum today and more as needed. In between the two loans, however, the debtor borrows from another lender who was willing to be junior to the first sum loaned but who under existing law thinks he is senior to later advances. In so far [sic] as existing law gives the first lender priority for his later advances only if he was obligated to make these advances this section changes the law. Under subsection (1) the first Iender has priority for all advances whether he is obligated to make them or not. ...

and 3 ALI \& National Conference of Commissioners on Uniform State Laws, Unifora Commercial CODE-OfficiaI Draft 772-75 (1952) text:

Section 9-312. Conflicting Security Interests: General Rules of Priority.

When conflicting security interests attach to the same collateral, such interests rank in the order of time of perfection with the following exception:

-...

(2) A secured party who has a perfected security interest and who makes later advances to the debtor on the same collateral and under the same security agreement takes priority as to the later advances from the time when his security interest was originally perfected.

and Comments:

Section 9-204 validates security agreements which provide for the secured party 


\section{Effect of the Priortty Rules on Secured Future AdVANCES LENDING}

\section{A. Facilitation of Secured Lending and Availability of Capital to Borrowers as Affected by Administrative Expense}

To the extent that it increases the expense of administering a discretionary future advances loan because the secured lender must make increased checks of the public record, the first, or qualified priority, rule would seem to thwart both a policy that secured lending should be facilitated ${ }^{47}$ and a policy that capital should be available to borrowers under a discretionary future advances arrangement. ${ }^{48}$ The second, or full priority rule, on the other hand, would further both policies by dispensing with the practical necessity of checking for intervening interests before disbursement of discretionary advances. If a burden is imposed by the first rule, it may not be uniform, because the proportion of the administrative expense to the aggregate value of a loan will vary with the number of disbursements made by the lender. When a building contractor is financed on security of his accounts and contract rights,

to make a series of advances against the same collateral. Under such a future advance agreement the situation described in example (b) may arise. [A makes a loan on equipment; $B$ then makes an advance on the same collateral. Thereafter A makes an additional advance claiming his "future" advance is entitled to the same priority as his first.] Subsection (2) provides that advances made under the future advance agreement take priority from the time the security interest was originally perfected and consequently prevail over intervening advances made by later secured parties.

This statutory history, it may be argued, shows a significant shift or shifts in the draftsmen's intent. At first, as shown in the 1949 Revision of Article 7 (the former version of Article 9), the draftsmen adopted an approach which gave the secured future advances lender only limited priority over third parties; his string of protected advances could be broken by an intervening secured lender. Later, however, this approach was abandoned in favor of one which, as shown in the 1950 and 1952 drafts, gave the lender absolute priority over the intervening secured party (provided he did not have a purchase money security interest) and, a fortiori, over the intervening judgment creditor. Those who favor greater protection of the future advances lender could argue that since no Code provision expressly negatives the draftsmen's final approach, that approach should be adopted as controlling ambiguous provisions. As a result the secured lender would receive absolute priority over intervening lien creditors and intervening secured lenders who perfect other than by filing.

Those who favor less protection for the future advances lender could argue that there have been two major shifts of the draftsmen's intent, not merely one. The first shift is that described by the proponents above: from less to greater protection. The second, however, is the reverse of the first; it is manifested by the 1958 amendment of the approach adopted in the Official 1952 draft (absolute priority over the intervening secured party). The failure to readopt the 1952 approach in any later version of the Code is only further evidence of the draftsmen's commitment to a less expansive view of the future advances lender's protection. Cf. UCC \& 9-312.

47 See Comment, UCC \& 9-101.

48 See, e.g., Pemberton, Notice Filing for Assignments of Accounts Receivable, $13 \mathrm{LAw}$ \& Contemp. Prob. 643, 651 (1948). 
for example, advances are relatively infrequent. ${ }^{49}$ In other future advances contexts, advances are more frequent. Use of a future advances arrangement to finance the customer credit purchases of a department store, for example, would appear to impose a greater administrative expense. ${ }^{50}$ The first rule may not, however, impose greater administrative expense, since it has been repeatedly stated that in practice lenders seldom check public records for claims on the borrower's assets. Instead, they rely on credit-rating services to supply information about financial standing. ${ }^{51}$ As far as administrative expense is concerned, then, it may be that as a practical matter neither rule will materially affect either the policy of facilitating secured lending or the policy of promoting the availability of capital under a discretionary advances arrangement.

\section{B. Encouragement of Salvage Lending}

If risky entrepreneurial activity is being funded, future advances lending and financial crises may go hand in hand. Whenever a lender is making advances on a discretionary basis to a concern which is on the verge of insolvency, ${ }^{82}$ the lender has the choice of continuing to

49 See, e.g., Hartford Accident \& Indem. Co. v. State Pub. School Bldg. Auth., 26 Pa. D. \& C2d 717 (1961).

50 See Dunham, Inventory and Accounts Receivable Financing, 62 HARv. L. REv. 588, 596 (1949); Kripke, The "Secured Transactions" Provisions of the Uniform Commercial Code, 35 VA. L. REv. 577,582 (1949).

51 Burman, Practical Aspects of Inventory and Receivables Financing, 13 LAw \& CONTEMP. ProB. 555, 558 (1948); Dunham, Inventory and Accounts Receivable Financing, 62 HARv. L. Rev. 588, 610 (1949); Pemberton, Notice Filing for Assignments of Accounts Receivable, 13 LAw \& Contemp. Prob. 643, 652 (1948).

52 If the future advances priority question is decided in the bankruptcy courts, one may speculate on which view of the security interest-the more restricted discrete interests view or the broader single interest view-the courts will adopt. Under the Bankruptcy Act section 60(a), I1 U.S.C. $\$ 1,30$ Stat. 544 (1898), as amended, 52 Stat. 883 (Chandler Act) (1938), it has been held that the giving of priority to the secured lender is not a voidable preference. Alternative grounds have been offered for this conclusion. In In re Bernard \& Katz, Inc., 38 F.2d 40 (2d Cir. 1930), the court upheld the secured lender's interest on the ground that the future advances substituted for the collateral he had taken. Okin v. Isaac Goldman Co., 79 F.2d 317 (2d Cir. 1935), upheld the security interest on the ground that the preference is not voidable because given for present consideration. The soundness of the view that the advance actually replaces the collateral taken has been questioned, and it has been suggested that advances close to bankruptcy may actually be dissipated. See Marsh, Book Review, 13 U.C.L.A.L. Rev. 898, $901-03$ (1966). Since an award of priority to the future advancing lender does amount to a removal of collateral from the debtor's other creditors, and given the uneasy status of the after-acquired property clause-see Gordon, The Security Interest in Inventory under Article 9 of the Uniform Commercial Code and the Preference Problem, 62 Colum. L. REv. 49 (1962)-to which the future advances arrangement is sometimes compared-see Coogan, 77 HARv. L. REv. 997, 1028; 72 Harv. L. REv. 838, 868-it may be that the courts will not award preference to any future advances 
supply capital in the hope that the enterprise will weather the financial storm or, for a complex of reasons, of refusing to lend further. Adoption of the second, or full priority rule (the single interest security interest) may prompt the lender to extend further credit, since he will know that he will receive priority over a lien creditor for discretionary advances made subsequent to the intervention of a lien creditor's interest. ${ }^{63}$ It is difficult to assess the impact of the full priority rule since many factors may influence the lender's decision. It may depend upon the amount of capital already invested in the business which he stands to lose, the calculated amount that will be needed to pull the business through, and the lender's estimate of the probability that added capital is indeed the proper remedy for the concern's financial ills. Perhaps, indeed, these latter considerations claim paramount importance in the lender's decision whether or not to continue disbursements.

-see In re Jeavons, 2 U.C.C. Rep. 644 (D.C.N.D. Ohio 1965)-or will limit priority to only those advances which the lender has obligated himself to make.

Under section 70(c) the language of UCC \& 9-301(3), note 29 stpra, it has been held that a trustee in bankruptcy qualifies as a "lien creditor" without notice as a matter of law. In re Babcock Box Co., 200 F. Supp. 80 (D.C. Mass. 1961). For the priority problem to arise the lender must make advances after the party becomes a lien creditor, i.e., on the date the petition in bankruptcy is filed. This situation could occur when a trustee asserted the rights of an assignee for benefit of creditors, see In re Komfo Products Corp., 247 F. Supp. 229 (E.D. Pa. 1965), and after-assignment advances are made by the secured lender. It could also arise if "charge-backs" were created after the petition in bankruptcy was filed. See In re Frederick Speier Footwear Corp., 129 F. Supp. 434 (D.C. Conn. 1955). It seems that in the first situation, advances after assignment for benefit of creditors but before petition in bankruptcy is filed, there must be compelling reason to allow preference to the secured party, because advances are so close to the bankruptcy period. The bankruptcy courts may find that compelling reason only when advances are made pursuant to a binding commitment. In the "charge-back" situation no advances, strictly, are made after the lien creditor appears, but the lien creditor will be seeking a substitution of collateral for those accounts lost. Here, too, the creditor may have to provide compelling reason to be given priority.

In the bankruptcy context, then, an institution which is at least partially dedicated to the protection of creditors who are unsecured-see GILMORE \$ 45.2; Note, Some Possible Areas of Conflict Between the Illinois Uniform Commercial Code and the Bankruptcy Act, 1962 IrL. L.F. 418-the argument for a restricted view of the secured creditor's security interest may prevail. As one commentator has concluded:

[This note] has suggested that in view of the potential conflict between the policy of the Bankruptcy Act in securing equality of distribution in bankruptcy and the policy of the Code of facilitating the perfection of security interests that will hold up in bankruptcy ...., the bankruptcy courts may tend to deal harshly with the provisions of the Code, feeling that they contravene the spirit or the letter of the Bankruptcy Act and leave unsecured creditors with inadequate remedy in bankruptcy contests. Note, supra at 487.

It may be conjectured, then, that the secured lender will be given priority only for those advances made pursuant to a binding commitment.

53 See Llewellyn, Problems in Codifying Security Law, 13 LAw \& ConTEMr. Pros. 687, 692 (1948). 


\section{Effect of the Priority Rules on Other SOURCES OF CREDIT}

One or the other priority rule for future advances may affect other sources of credit available to the borrower. If the second, full priority, rule is adopted, the borrower may find himself little more than a peon of his future advancing lender, ${ }^{54}$ because other sources of credit, secured or unsecured, may be closed to him. Conceivably, secured lenders might be deterred from lending money to a borrower whose assets were tied up in one secured lender for all present and future discretionary advances. Conversely, adoption of the first, qualified priority rule might open up sources of credit for the borrower. Under the first rule other secured lenders perfecting their security interest other than by filing would be willing to advance money because assured of priority over the first secured lender's subsequent discretionary advances. The practical significance of these speculations depends, at root, on whether lenders employ broad future advances and after-acquired property clauses to obtain a kind of financial strangle hold on their borrowers, and, given the first lender's position, on whether the lending practices of subsequent creditors would be influenced if the best available claim to the borrower's property was a second lien on his collateral. For prudent business reasons, sweeping future advances and after-acquired property arrangements (the Code's "floating lien") may not be used even though technically they are available. ${ }^{55} \mathrm{It}$ has been reported, however, that some lenders make a conscious effort to exclude other lenders by obtaining a powerful grasp over the borrower's collateral. ${ }^{58}$

But even if the broad hold were obtained, other secured lenders may not be deterred from making secured loans. Security has a threat value as well as a monetary value; removal of an inexpensive but crucial piece of equipment from a plant may interrupt its entire operations. ${ }^{57}$ Lenders may be willing to take second place if they are able to use a threatened foreclosure of a security interest as an inducement for payment. Furthermore, lenders apparently are willing to loan to those heavily financed, and rely on matters other than the value of unencumbered assets to determine whether or not to extend credit. These matters include the financial standing of the borrower's customers, the estimated capacity of the borrower to maintain and extend his ac-

54 For an expression of concern about this policy, see, e.g., Llewellyn, Problems of Codifying Security Law, 13 LAw \& ConTEMP. ProB. 687, 691 (1948).

is See Coogan, Operating under Article 9 of the Uniform Commercial Code Without Help or Hindrance of the "Floating Lien," 15 Bus. LAw. 373 (1960).

56 See G. Contes, Law and Practice in Chattel Secured Farm Credit 8-9 (1954).

57 See Hadley v. Baxendale, 9 Wels. 341, 156 Eng. Rep. 145 (Ex. 1854). 
counts, and the lender's hunch as to the probable success of the investment. ${ }^{58}$ As a practical matter, then, the second, or full priority rule may not materially reduce the availability of other secured credit to the borrower. Either lenders may not attempt to grab up all the debtor's collateral as security for all advances now and in the hereafter, or if they do, subsequent secured lenders may be willing to extend credit anyway.

The second, full priority, rule might conceivably reduce unsecured credit available to the borrower just as it could conceivably reduce the availability of other secured credit available to the borrower. ${ }^{69}$ As in the secured creditor situation discussed above, estimating the effect of the presence of security interests in collateral on lending practices is difficult. ${ }^{00}$ For example, even assuming the existence of acquisitive lending practices by secured lenders, competitive pressures may force creditors to continue to extend unsecured credit, ${ }^{61}$ distasteful though it may be. Unsecured lending in general has apparently not suffered by adoption of the Code, for a drop in the proportion of unsecured to secured credit has not occurred in Code states, at least if reports after five ${ }^{82}$ and ten years ${ }^{\prime 3}$ experience with it are accurate. Of course, the constancy of the proportion of unsecured to secured credit in general does not mean that there has been no shift in the proportion in the specific context of discretionary future advances. Furthermore, since no state has yet construed the Code's ambiguous future advances priority sections, unsecured lenders may be unaware of their vulnerability under the second, full priority rule.

\section{Equitable Considerations: Doing What Is Fair}

As remarked earlier, one's inquiry may focus more directly upon the immediate parties to the dispute in an effort to determine what pri-

58 See Burman, Practical Aspects of Inventory and Receivables Financing, 13 LAw \& Contemp. Pros. 555, 558 (1948); Skilton, The Factor's Lien on Merchandise, 1955 WIs. L. REv. 609, 625 n.46.

59 A fear of reducing the availability of unsecured credit by adoption of the Code has been expressed. See Dunham, Inventory and Accounts Receivable Financing, 62 Harv. $L$. REv. 588, 614 (1949); Hogan, Future Goods, Floating Liens, and Foolish Creditors, 17 STAN. L. REv. 822 (1965).

60 "[T] he degree to which merchandise creditors are affected in their actual contracting and deliveries by knowledge of the existence of a lien on inventory or receivables or both is as uncertain a territory of human behavior as there is." Llewellyn, Problems of Codifying Security Law, 13 LAw \& ConteMP. Prob. 687, 698 (1948).

61 See A. FArNsworth \& J. Honnold, Commercial LAW 309 (1965).

62 Schnader, The Unsecured Creditor-“"The Little Businessman" and the Uniform Commercial Code, 1 B.C. IND. \& CoM. L. REv. 65 (1959).

68 See National Conference of Commissioners on Uniform State Laws, The Uniform Commercial Code in Pennsylyanis, 1954-1964, and in Massachusetts, 1958-1964: ExPERIENCE, NOT THEORY (1964). 
ority result is "fair." Of course, in choosing one or the other of the available priority rules on the basis of "fairness" one lessens or increases the risk which the institutional lender is taking and thus conceivably affects the availability of the secured future advances loan. Either situational or particular equities, to use Llewellyn's terms, ${ }^{64}$ could be used as a basis for deciding what is fair. If one creates a rule with an unvarying result, if the single interest rule is adopted, then individual cases may have harsh results, but overall the system is fair because its certainty creates expectation upon which all may act. Thus, once the secured creditor has perfected his security interest all the world knows the extent of his security interest and may act accordingly. Of course, not everyone becomes a creditor voluntarily, such as the victim of a borrower's tortious act.

The pre-Code common and statutory law, however, seems to have focused more upon particular than situational equities. The pre-Code future advances priority rule, with variations, is simple enough. ${ }^{65}$ If the secured party had contractually bound himself to make advances, he was given priority from the date of the execution ${ }^{68}$ or recordation ${ }^{67}$ of the security agreement, often a mortgage, "over all subsequent encumbrances to the extent of all advances actually made, regardless of whether or not they were made before or after the junior encumbrance, and regardless of whether or not the advancer had constructive or actual notice of the intervening lien." 68 When the lender made the advances solely at his discretion, the subsequent advances were subordinate to an intervening lien of which the lender had notice, actual or constructive. $^{69}$ By making a distinction between obligatory and discretionary advances, the courts gave greater protection to the lender who had taken the greater risk of binding himself to a course of dealing

64 K. Lueweilyn, The Common law Tradition: Deciding Appeals 268-85 (1960).

68 See Gilmore \$\$ 35.2-35.4: 1 G. Glenn, Fraudulfent Conveyances and Preferences $\$ \$$ $372-73$ (rev. ed. 1940); 3 G. GLEN, Mortgages: $\$ \$ 392-408$ (1943); 1 L. Jones, Chattei Montgages and Conditional Sales \$\$ 94-98a (6th ed. 1933); 1 L. Jones, Mortanges $\$ \$ 447-62$ (8th ed. 1928); G. Osborne, Mortgages $\$ \S$ 113-24 (1951); $4 \mathrm{~J}$. Pomeroy, Equity Jurisprudence $\$ \$ 1197-99$ (5th ed. 1941); Blackburn, Mortgages to Secure Future Advances, 21 Mo. L. REv. 209 (1956); Jones, Mortgages Securing Future Advances, 8 TexAs L. Rev. 371 (1930); Note, Comparison of Real Property Mortgages and Security Interests in Chattels to Secure Future Advances, 36 ConN. B.J. 463 (1962); Note, Mortgages Securing Future Advances-A Need for Legislation, 47 IowA L. REv. 492 (1962); Note, Refinements in Additional Advance Financing-The "Open End" Mortgage, 38 MiN. L. REv. 507 (1954); Annot, 172 A.L.R. 1079 (1948); Annot., 152 A.L.R. 1182 (1944); Annot., 138 A.L.R. 566 (1942); Annot, 81 A.L.R. 631 (1932); Annot., 53 A.L.R. 580 (1928); Annot., 5 A.L.R. 398 (1920).

68 E.g., Hawaii Laws ch. 172, \& 1 (1951), 1 L. JonEs, MORTGAGes \& 454 (8th ed. 1928).

67 E.g., Fla. Laws ch. 63-212, \$\& 3, 4 (1963).

08 Blackburn, Mortgages to Secure Future Advances, 21 Mo. L. REv. 209, 219-20 (1956) (footnotes omitted).

69 See, e.g., id. 2t 223-32. 
with the borrower. Two assumptions implicit in this last statement can be questioned. First, as the discussion in the note ${ }^{70}$ illustrates it may not be fair at all to give the obligated lender special status, since, as a practical matter, he may be able to freely breach his promises to lend. Second, even if there is a real difference between obligatory and discretionary advances in its administration, a rule based on the distinction may actually release the courts from any standards of fairness. Just how "particular" an approach the courts took has been the subject of lively debate among the commentators. Some believe that the pre-Code rule was in actual practice a cover-up for unlimited judicial discretion over priority questions. One might expect that the use of a simple rule of priority in a wide variety of contexts would, with the change in business conditions over time, necessarily lead to a proliferation of exceptions, making the rule more honored in the breach than in the observance. Such a fate has befallen other common law rules. ${ }^{71}$ The statement of simple common law and statutory rule of future advances priority, however, remained essentially the same for over a century. ${ }^{72}$ At least two possible explanations can be given for the rule's longevity. On the one hand, the courts may have used the rule's distinction between obligatory and discretionary advances as a convenient tool to fix priorities in accordance with whatever reasons seemed persuasive in the particular case. They could first pick the party to whom they wanted to award priority and then construe the future ad-

70 It has been argued that in legal theory even "unconditionally binding" advances are discretionary: If the advancing party breaches his promise to make obligatory advances, he may not be forced to perform on his contract. Rather, the damages to the borrower are the difference, if any, between the rate of interest which the borrower was required to pay under his loan with the lender, and the new interest rate which he is required to pay when he seeks to borrow the money which he was promised. If the difference in interest rates is large, then that difference will not be regarded as a proximate result of the lender's breach, but rather as a result of the borrower's lowered credit standing or as the result of a tightened money market. Thus, the lender, although "obligated" to make advances, may breach with little fear of serious legal sanction. See GuMOre \& 35.5; G. OsBorne, MORTGAGES \$ 117a n.39 (1951) and accompanying text. However, it may be argued that the economic injury imposed by the legal sanction is not the only deterrent to the breach of a contract to lend money. The lender's reputation in the business community depends upon honoring commitments which are regarded as binding, however weak the legal sanction which enforces the commitment. If the lender freely breaches his lending agreements few borrowers will be attracted to him as a source of credit. Coogan, 77 HARv. L. REv. 997, 1031, would take issue with Professors Gilmore and Osborne: "Both commercially and legally there is a world of difference between advances which a secured party is committed to make and those which he can make or refuse at his option."

71 See, e.g., discussion of the rule that an obligor can prohibit the assignment of a contract claim, RESTATEMENT OF CONTRACTs \& 151(c) (1932), in GILMORE § 7.6.

72 For an early statement of the rule, see Boswell v. Goodwin, 31 Conn. 74, 87 (1862) (dissenting opinion of Butler, J.). For later statements see cases collected in works cited note 65 supra. 
vances contract to reach the desired result. On the other hand, it may be that the rule's long life is attributable to judicial satisfaction with the balancing of conflicting interests which conscientious application of its distinction between obligatory and discretionary advances could achieve. Analysis of the cases to discover what the courts were in fact doing is made difficult because it is impossible to tell whether the courts are accurately reflecting the contracts before them.

The case of Omaha Coal, Coke \& Lime Co. v. Suess ${ }^{73}$ illustrates the second guessing that seems necessary in the analysis of future advance priority cases. In that case a mortgagee under a future advances agreement had received actual notice of an intervening judgment in favor of a creditor of the mortgagor. The question of priority for advances made subsequent to that notice, therefore, depended upon whether the advances were made pursuant to a binding commitment or at the lender's discretion. The facts of the case showed something of a requirements arrangement between the secured lender and borrower in return for a promise of exclusive agency. Zimmerman, the borrower-mortgagor, delivered a deed of his real estate to an agent of the Anheuser-Busch Brewing Association, the future advancing mortgagee, to secure advances of beer for bottling purposes. In return, Zimmerman agreed to sell only Anheuser's beer. According to the court, Anheuser's promise was merely a vague agreement, not a binding contract, and, as a result, the judgment creditor was awarded priority over the subsequent advances.

At least two interpretations of the case seem possible. On the one hand, it could be that the court was manipulating the concept of a binding "contract" to give priority to the general creditor for some persuasive equity which does not appear in the report. ${ }^{74}$ Perhaps the contract, if accurately reflected, would clearly make Anheuser's subsequent advances binding. On the other hand, the agreement between Anheuser and Zimmerman may be correctly described in the opinion, and the enforceability of their agreement at this point in time may have been genuinely doubtful.

If the manipulative interpretation is taken, then a rule based upon a distinction between binding and discretionary advances would be no rule at all, but merely a judicial tool for the working of "justice" in light of the particular facts of each case. If this interpretation is correct, no lender could ever be sure that he would be awarded priority commensurate with the degree of risk he supposed he was undertaking when discretionary and thus that courts have a rather free hand in deciding priority questions. 
he had "bound" himself to make advances. It seems unlikely that courts would be willing to cripple a lending device of which they thought so highly by increasing the risk associated with it, or to deliberately misread an agreement which all agreed was a binding commitment in every other respect, just because the secured lender knew of an intervening claim when he made a subsequent disbursement. Moreover, the non-manipulative interpretation makes the Omaha Coal case consistent with contract law of the time. Although requirements contracts won the battle for legal validity, authority indicates that at the turn of the century they were not enforceable. ${ }^{75}$

The courts, then, seemed to think it fairest to subordinate the secured lender's discretionary advances. One may well question the soundness of this decision today, when all persons who voluntarily become creditors have ready access to credit information under the Code's filing system.

\section{Concrusion}

The Uniform Commercial Code has not achieved its ambitious task of clearly assigning priorities to the security interests which it creates. Depending upon the conception of the security interest which is adopted, the future advances secured party may or may not receive priority over intervening lien creditors or holders of security interests perfected other than by filing. As a result, logical deduction alone cannot solve the priority question. Generally, efforts to resolve it have focused upon the conceptualistic problem of the "proper" view of the Code "security interest." Analysis of the priority question in terms of the policies that the alternative rules could further reveals'a number of difficulties largely of an empirical nature. Since such distinct, conflicting, and interrelated policies are so obviously involved, in fairness to all citizens, the legislature and not the courts should resolve the future advances priority issue by specific amendment of the Code. In addition, legislative inquiry might be able to answer the complex question of the effect of a given priority rule upon these policies.

For the time being, however, in the interests of favoring overall Code policies of simplicity and protection of secured lending, it seems appropriate, on balance, to adopt the second, or absolute priority rule. If it proves sufficiently objectionable to award the secured lender priority even for his discretionary advances, a remedy is available in the form of a legislative amendment.

75 See K. Lnewerlyn, The Comanon Law Trabimon: Deciding Appeals 242 (1960) (discussing the New York "indefiniteness" cases); Havighurst \& Berman, Requirement and Output Contracts, 27 ILL. L. REv. 1 (1932); Corbin, The Effects of Options on Consideration, 84 Yale L.J. 571 (1925). 